\title{
Molecular Characterization and Phylogenetic Analysis of Canine Parvovirus 2 in Dogs, Mersin Province, Turkey
}

\author{
Ender Dinçer \\ Mersin University, Advanced Technology Education, Research and Application Center, Mersin
}

Geliş Tarihi / Received: 10.10.2017, Kabul Tarihi / Accepted: 02.11.2017

\begin{abstract}
Canine parvovirus type $2(\mathrm{CPV}-2)$ is a highly contagious and lethal viral disease with acute gastroenteritis in young dogs. After it first appeared in USA in 1978, continuous evolution of virus genome has arisen new genetic and antigenic variants such as CPV-2a, CPV-2b, new CPV-2a, new CPV-2b and CPV-2c throughout the world. The aim of the present study was to detect CPV-2 genetic variants from blood samples of clinically ill dogs and to characterize CPV2 genetic variants circulating in Mersin province (Turkey), by partial sequence analysis of VP2 gene. A total of 20 blood samples were collected from dogs with gastroenteritis from local veterinary clinics between April 2017 to September 2017. Out of 20, 7 samples were positive for CPV-2 genomic DNA using conventional PCR. Amino acid comparisons showed that Ile-324 mutation was detected in the VP2 of clinical CPV-2b samples, as differ previously studies Turkish genetic variants. A phylogenetic tree constructed based on VP2 gene sequences indicated that CPV-2b sequences from Mersin province were related to Indian genetic variants. Moreover, CPV-2b sequences from Mersin have clustered separately from other Turkish CPV-2b genetic variants previously reported. The results show that CPV- $2 \mathrm{~b}$ genetic variant is circulating among in dogs in Mersin province.
\end{abstract}

Key words: Canine parvovirus, dog, phylogenetic analysis, VP2 gene.

\section{Türkiye'de Mersin İlinde Köpeklerde Canine Parvovirus 2'nin Moleküler Karakterizasyonu ve Filogenetik Analizi}

\begin{abstract}
Özet: Canine parvovirus 2 (CPV-2) genç köpeklerde akut kanlı gastroenteritis ile seyreden oldukça bulaşıcı ve ölümcül bir viral hastalıktır. 1978'de ABD'de ilk ortaya çıtıktan sonra, virus genomunun sürekli evrimi, tüm dünyada CPV2a, CPV-2b, new CPV-2a, new CPV-2b ve CPV-2c gibi yeni genetik ve antijenik varyantların ortaya çıkmasına yol açmıştır. Bu çalışmanın amacı, Mersin (Türkiye) ilinde klinik olarak hasta köpeklerin kan örneklerinde CPV -2'yi tespit etmek ve dolaşımda olan CPV- 2 genetik varyatlarının karakterizasyonunu sağlamaktır. Bunun için 2017 Nisan ve 2017 Eylül ayları arasında, yerel kliniklerden 20 adet kan örneği gastroenteritisli köpeklerden topland1. 20 örneğin 7'si PZR ile CPV- 2 yönünden pozitif olarak test edildi. Klinik CPV-2b örneklerinin VP2'sindeki amino asit karşılaştırmaları sonucunda daha önce çalışılan Türk soylarından farklı olarak Ile-324 mutasyonu tespit edildi. VP2 geni dizinlerinden köken alarak yapılan filogenetik ağaç, Mersin ilinden gelen CPV-2b dizilerinin Hindistan genetik varyantlarıyla ilişkili olduğunu göstermiştir. Aynı zamanda Mersin ilinden elde edilen CPV-2b dizinleri daha önce tespit edilen Türk genetik varyantlarından farklı bir dal şekillendirmiştir. Bu sonuçlar Mersin ilinde CPV-2b genetik varyantının köpekler arasında dolaştığını göstermiştir.
\end{abstract}

Anahtar kelimeler: Canine parvovirus, köpek, filogenetik analiz, VP2 gen.

\section{Introduction}

Canine parvovirus 2 (CPV-2) is small, non-enveloped, single-stranted DNA virus, belonging to genus Parvovirus, the family Parvoviridea with genome Of 5, $2 \mathrm{~Kb}$ in lenght. CPV-2 has two open reading frames (ORFs). One of them encodes non-structural proteins (NS1, NS2) and the other encodes structural proteins (VP1, VP2). Amino acid changes in the VP2 protein, main viral protein of capsid, alter the antigenic properties of the virus in determining the viral host distribution and tissue tropism $[6,13]$.
After the emergence of the CPV-2 in 1978, two new genetic variants (CPV-2a and CPV-2b) were characterized in 1979 and 1984, respectively. Monoclonal antibodies can distinguish as CPV-2a (426Asn) and CPV-2b (426Asp) by amino acid substitution in the capsid protein gene. In 2000, CPV-2c (Asp426 to Glu) is a new genetic variant was detected in Italy $[6,11]$. These three genetic variants occur in dogs throughout the world; CPV-2a was found in Nigeria, South Africa, Turkey, Greece and other European countries [14]. CPV-2b was reported from USA, Turkey and China [6, 23]. Morever,

Yazışma adresi / Correspondence: Ender Dinçer, Mersin University, Advanced Technology Education, Research and Application Center, Çiftlikköy, Mersin, Turkey E-posta:enderdin@gmail.com 
CPV-2c has been reported in Italy, Spain, Germany, the United Kingdom, the United States, Australia, Portugal, Vietnam and some other European countries $[1,5,7,10,12,13,19]$.

CPV-2 is a highly contagious disease that causes acute hemorrhagic enteritis and myocarditis in dogs with high fatality rate ranges from $\% 24$ to $\% 43[26,27]$. The virus is usually transmitted through direct contact from dog to dog or acquired indirectly environment contaminated with feces [27]. Although CPV-2 is common in all dogs, puppies between 6 weeks and 6 months are more susceptible to disease. The incubation period of disease is between 3 and 7 days and main characteristics of the disease are depression, loss of appetite, fever, vomiting, hemorrhagic diarrhea and dehydration. Vaccination is main method of protection from disease. Commercial vaccines are available for CPVs genetic variants worldwide and are able to protect against 4 genetic variants; CPV, CPV - 2a, CPV$2 \mathrm{~b}$ and CPV- 2c respectively [13]. CPV vaccines (Vanguard, Pfizer; Nobivac, Intervet; Parvodog, Merial; Quantum, Schering) used for dogs include $2 \mathrm{a}$ and $2 \mathrm{~b}$ genetic variants in Turkey. However, anti- genic changes occurring in the VP2 protein of CPV reduce efficacy of vaccine in dogs [23]. Mutations such as 87, 101 297, 300,305, 323, 324, 426, 440, 555 occurring of VP2 protein of CPV result in new genetic variant and pathogenic features [21, 25]. Carmichael et al.,[3] reported that CPV -2 variants were detected higher titres than original virus in faeces of naturally infected dogs.

The aim of the present study was to detect CPV from blood samples of dogs and to characterize CPV genetic variants circulating in Mersin province (Turkey), by partial sequence analysis of VP2 gene.

\section{Materials and Methods}

\section{Sample collection}

Blood samples $(n=20)$ were obtained from local veterinary clinics in Mersin province between April and September 2017. Anticoagulated blood samples were centrifuged at $3000 \mathrm{rpm}$ for 7 minutes and the buffy coat was collected and stored at $-20^{\circ} \mathrm{C}$ until use. Individual information such as age, gender, breed, clinical symptoms and vaccination history about the animals involved the study is given in Table 1.

Table 1. Year, sample type, Age, gender, vaccination status, clinical sings of dogs infected and non - infected with CPV - 2b (F: Famale, M: Male, NV: Non - vaccinated).

\begin{tabular}{|c|c|c|c|c|c|c|c|}
\hline Year & Sample type & Age(month) & $\operatorname{Sex}$ & $\begin{array}{c}\text { Vaccination } \\
\text { status }\end{array}$ & Clinical symptoms & Type & Breed \\
\hline 2017 & Blood 1 & 1,5ay & $M$ & NV & Depression, vomiting & - & Mix \\
\hline 2017 & Blood 2 & $2 a y$ & $\mathrm{~F}$ & NV & Diarrhea & CPV -2b & Mix \\
\hline 2017 & Blood 3 & 2ay & $\mathrm{F}$ & NV & Anorexia,anemia depression & - & golden retriever \\
\hline 2017 & Blood 4 & 3ay & M & NV & Anorexia, vomiting & - & german shepherd \\
\hline 2017 & Blood 5 & 1,5 & $\mathrm{~F}$ & NV & diarrhea & $\mathrm{CPV}-2 \mathrm{~b}$ & german shepherd \\
\hline 2017 & Blood 6 & 5 ay & $\mathrm{M}$ & NV & Anorexia, Diarrhea & - & Mix \\
\hline 2017 & Blood 7 & 2ay & $\mathrm{M}$ & NV & Diarrhea & - & Mix \\
\hline 2017 & Blood 8 & 3ay & $\mathrm{M}$ & NV & Diarrhea & - & rottweiler \\
\hline 2017 & Blood 9 & 1,5 & $\mathrm{~F}$ & NV & Diarrhea & - & pointer \\
\hline 2017 & Blood 10 & 3ay & $\mathrm{F}$ & NV & Anorexia, vomiting & - & pointer \\
\hline 2017 & Blood 11 & 2ay & $\mathrm{F}$ & NV & Anorexia, vomiting & $\mathrm{CPV}-2 \mathrm{~b}$ & Mix \\
\hline 2017 & Blood 12 & 1,5 & M & NV & Depression, vomiting & $\mathrm{CPV}-2 \mathrm{~b}$ & Mix \\
\hline 2017 & Blood 13 & 2ay & M & NV & Diarrhea & $\mathrm{CPV}-2 \mathrm{~b}$ & golden retriever \\
\hline 2017 & Blood 14 & 1,5 & M & NV & Diarrhea & - & golden retriever \\
\hline 2017 & Blood 15 & 2ay & $\mathrm{F}$ & NV & Vomiting, diarrhea & - & Mix \\
\hline 2017 & Blood 16 & 2ay & M & NV & Anorexia, depression & CPV -2b & Mix \\
\hline 2017 & Blood 17 & 3ay & M & NV & Diarrhea & - & Mix \\
\hline 2017 & Blood 18 & 1,5 ay & M & NV & Vomiting & CPV -2b & golden retriever \\
\hline 2017 & Blood 19 & 2 ay & $\mathrm{F}$ & NV & Vomiting & - & rottweiler \\
\hline 2017 & Blood 20 & 5ay & M & NV & Anorexia, Diarrhea & - & rottweiler \\
\hline
\end{tabular}




\section{Template DNA Preparation and PCR}

Nucleic acids were extracted from $200 \mu \mathrm{L}$ blood samples using High Pure Viral Nucleic Acid Kit (Roche Diagnostics, Mannhaeim, Germany) following the manufacturer's recommendations. Purified DNAs were stored at $-20^{\circ} \mathrm{C}$ until PCR. The PCR targeting partial VP2 gene (629bp) was performed as described elsewhere [2]. Amplified PCR products were visualized under ultraviolet light via ethidium bromide staining after electrophoresis using in $\% 1$ agarose gel in TAE (Figure 1). Consequently, $100 \mu \mathrm{L}$ amplicon from each sample was purified using a commercial kit (GeneJET, Thermo Scientific, Lithuania) according to manufacturer's instructions. Purified DNA was used for DNA sequencing and subsequent phylogenetic analysis.

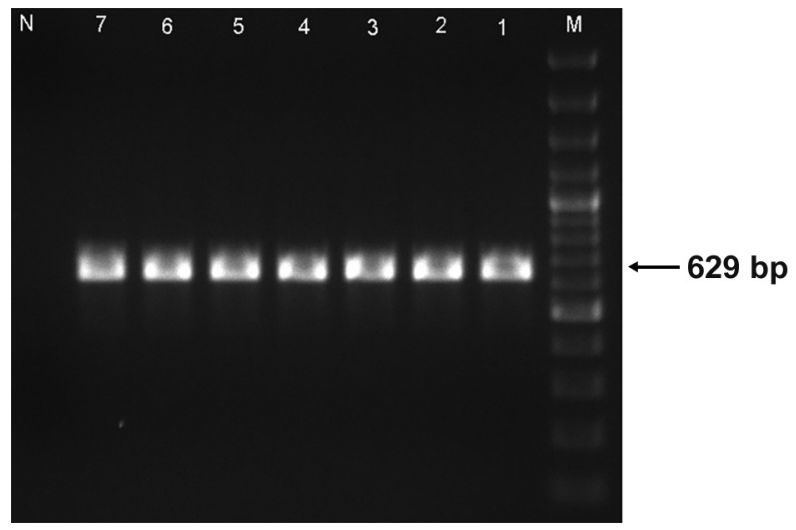

Figure 1. Agarose gel image of the PCR products (629 bp) of Canine parvovirus DNA using by Hfor and Hrev primers. Lane M: 100bp DNA ladder (Thermoscientific, USA); Lane: 1 - 7 positive samples; Lane 8: Negative control.

\section{DNA sequencing and phylogenetic analysis}

Sequencing was performed in ABI PRISM 310 Genetic Analyzer (Applied Biosystem, CA) using same primers that were used in the PCR. The obtained DNA sequences were compared to other CPV sequences available from GenBank Database (http://www.ncbi.nlm.nih.gov). Alignment and pairwise comparisons were carried out in CLC Main Workbench v7.7 (CLCBio, Aarhus, Denmark). Phylogenetic tree was drawn in MEGA software v.6.06 using neighbor-joining (NJ) method and bootstrap values were calculated with 1,000 replicates [19].

\section{Results and Discussion}

Twenty dogs with clinically defined gastroenteritis (especially vomiting and diarrhea) signs were tested with conventional PCR assay for the presence of CPV-2. Seven $(35 \%)$ of the dogs were CPV-2 positive. Samples from negative dogs were not reinvestigated for the other etiological causes of gantroenteritis. CPV- 2 positive dogs were between 1 , 5 and 5 months old. Four of the positive dogs were male and three were female. According to the information received from the pet clinics, no vaccination was administrated to dogs. Breeds of dogs involved the study were recorded as Rottweiler, Golden Retriever, Pointer, German Shepherd and mix breed (Table 1).

Conventional PCR was carried out using Hfor and Hrev primers. Sequence analysis of PCR amplicons were performed with same primer sets. The obtained sequence results were compared to gene bank reference sequences (Figure 2). Phylogenetic (NJ) analysis revealed that all CPV-2 detected in the study were found to be CPV-2b. Other genetic variants (CPV-2a and $\mathrm{CPV}-2 \mathrm{c})$ were not identified in the study. In order to investigate the variations occurring on VP2 gene, reference strain (GenBank Accession \# M38245) was compared to amino acid residues obtained from clinical samples (Table 2).

Table 2. Amino acid changes in VP2 partial gene of CPV - $2 b$ type

\begin{tabular}{|c|c|c|c|c|c|c|c|c|}
\hline Aa no. & 297 & 300 & 305 & 324 & 336 & 375 & 426 & 440 \\
\hline M38245 & $S$ & $\mathrm{~A}$ & $\mathrm{D}$ & $\mathrm{Y}$ & $\mathrm{A}$ & $\mathrm{N}$ & $\mathrm{N}$ & $\mathrm{T}$ \\
\hline P5 & A & G & $\mathrm{Y}$ & I & G & D & D & A \\
\hline P12 & A & G & Y & I & G & $\mathrm{D}$ & $\mathrm{D}$ & A \\
\hline P2 & A & $\mathrm{G}$ & Y & I & G & D & $\mathrm{D}$ & A \\
\hline P13 & A & G & Y & I & G & D & $\mathrm{D}$ & A \\
\hline P18 & A & G & $\mathrm{Y}$ & I & G & $\mathrm{D}$ & $\mathrm{D}$ & A \\
\hline P11 & A & G & $\mathrm{Y}$ & I & G & $\mathrm{D}$ & $\mathrm{D}$ & A \\
\hline P16 & A & G & Y & I & G & D & $\mathrm{D}$ & A \\
\hline Aa change & $\begin{array}{c}\mathrm{TCT} \rightarrow \mathrm{GCT} \\
\mathrm{S} \rightarrow \mathrm{A}^{*}\end{array}$ & $\begin{array}{c}\mathrm{GCT} \rightarrow \mathrm{GGT} \\
\mathrm{A} \rightarrow \mathrm{G}^{*}\end{array}$ & $\begin{array}{c}\mathrm{GAT} \rightarrow \mathrm{TAT} \\
\mathrm{D} \rightarrow \mathrm{Y}^{*}\end{array}$ & $\begin{array}{c}\mathrm{TAT} \rightarrow \mathrm{ATT} \\
\mathrm{Y} \rightarrow \mathrm{I}^{*}\end{array}$ & $\begin{array}{c}\mathrm{GTA} \rightarrow \mathrm{GTG} \\
\mathrm{V} \rightarrow \mathrm{V}\end{array}$ & $\begin{array}{c}\mathrm{AAT} \rightarrow \mathrm{GAT} \\
\mathrm{N} \rightarrow \mathrm{D}^{*}\end{array}$ & $\begin{array}{c}\mathrm{ATT} \rightarrow \mathrm{GAT} \\
\mathrm{N} \rightarrow \mathrm{D}^{*}\end{array}$ & $\begin{array}{c}\mathrm{ACA} \rightarrow \mathrm{GCA} \\
\mathrm{T} \rightarrow \mathrm{A}^{*}\end{array}$ \\
\hline
\end{tabular}

Amino acid substitutions are indicated by asterisks (*). 


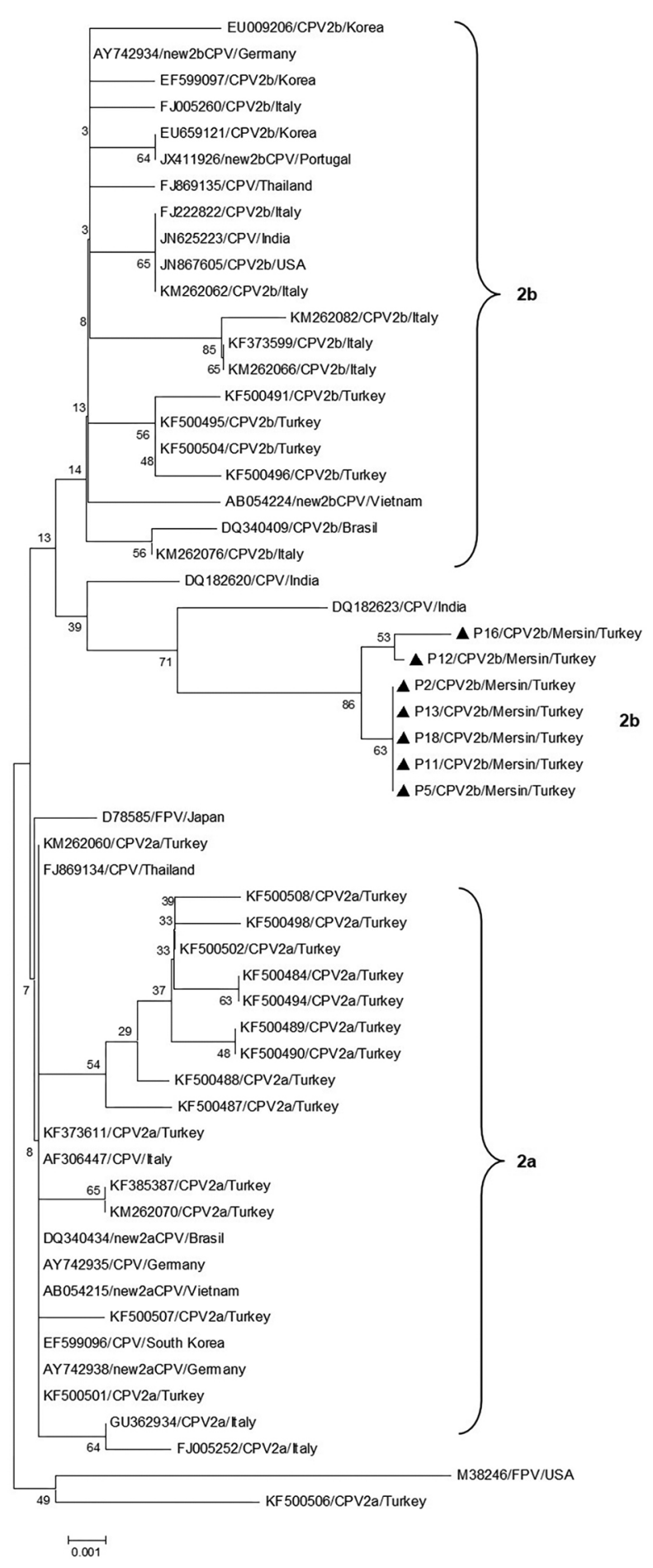

Figure 2. Neighbor joining tree (Mega 6) was constructed using canine parvovirus partial VP2 gene sequences under study (consensus sequences are indicated filled triangle in this study) and reference sequences.

Amino acid analysis revealed that all positive specimens were had a substitution N426D, which is characteristic of $\mathrm{CPV}-2 \mathrm{~b}$ variant $(\mathrm{A} \rightarrow \mathrm{G}$ transver- sion). Nucleotide variation at position 948 resulted in $\mathrm{A} \rightarrow \mathrm{G}$ (synonymous mutation) codon change from $\mathrm{GTA} \rightarrow$ GTG, they both encode the same amino acid $(\mathrm{V} \rightarrow \mathrm{V})$. In this study, substitutions were detected in S297A (nt3675), A300G (nt3685), D305Y (nt3699), Y324I (nt3757), N375D (nt3912) and T440A (nt4104) (Table 2). The residue T440A, which is known to be main antigenic site of the virus, locates at the three-fold spike on VP2 protein [6]. Synonymous and non-synonymous mutations have been described previous studies $[6,11,17,24$, 26]. However, mutation in residue Y324I was the first reported in Turkey genetic variants (Table 2). The Y324I mutation has been reported in CPV genetic variants in China, India, Korea and Japan [10, $16,18,22]$. It was reported that residue 324 shows strong positive selection all carnivore parvovirus. $[8,9]$. It is adjacent to residue 323 , which is responsible for host range like previously reported $[6,13$, 23] and residue 93, which determines the host distribution with binding canine transferrin receptor (TrR) [16]. As a result, residue 324 mutation may have a role on CPV host range together with residue 323 and 93. Although the function of the residue 324 is not fully known, Lin et al.,[9] reported that Ile324 mutation resulted in viral shedding up to 63 days in dogs. These mutations can lead to changes in the VP2 protein of CPV and cause new genetic variants. Moreover, the emergence of new genetic variants reduces the efficacy of vaccines used in the field [15].

Phylogenetic tree indicated that all CPV-2b genetic variants in Mersin province were closerelated and allocated in a separate branch (Figure 2). Comparison of CPV-2b VP2 sequences obtained from clinical samples were $99 \%$ identical to each other and CPV-2b sequences detected in this study were associated with $98 \%$ identical to Indian sequences.

CPV-2 is highly infectious and deadly viral disease of dogs seen in many countries around the world. Study performed in Greece showed that all three CPV-2 genetic variants (CPV-2a, 2b and 2c) are circulating in dogs [11]. In one of the most recent investigation Dei Giudici et al., [6] performed in dogs and cats, all variants CPV- $2 \mathrm{a} / 2 \mathrm{~b} / 2 \mathrm{c}$ have been shown to be in circulation by conventional PCR. Another study carried out in Lithuania re- 
vealed $\mathrm{CPV}-2 \mathrm{a}$ and $2 \mathrm{~b}$ genetic variants are present in dogs [26]. Moreover, CPV-2a has been reported in rectal swaps obtained from dogs in India [17]. In Turkey, there is limited number of studies on CPV genetic variants in dogs $[21,22,23]$. Timurkan et al., [20] carried out the first molecular characterization of CPV-2a and CPV-2b genetic variants in Ankara province. Results of the study showed presence of CPV-2b genetic variant in dogs in Mersin province. All of these investigations show that the CPV-2a and CPV-2b are predominant strains in dog population in Turkey and CPV-2c variant has not yet been identified in Turkey so far. Further molecular and epidemiological studies are needed to determine on CPV infections and to characterize circulating types in dogs.

In conclusion, the presence of amino acid mutations suggests that the virus has evolved continuously. Although parvovirus is a DNA virus, it has high genetic substitution rate, which causes emerging new genetic variants as well as RNA viruses [5]. Differences between field and vaccine strains are the most important reason for some immune failures [17]. Periodic epidemiological survey and molecular studies can be identified new CPV-2 genetic variants and mutations. In addition, comparison of strains obtained from different geographical areas can be provided the development of used vaccines and CPV 2 infections can be effectively controlled in the country.

\section{References}

1. Apaa TT, Daly JM, Tarlinton RE, (2016). Canine parvovirus (CPV2) variants circulating in Nigerian dogs. Vet Rec Open. 3, 1 -4.

2. Buonavoglia C, Martella V, Pratelli A, Tempesta M, Cavalli A, Buonavoglia D, Bozzo G, Elia G, Decaro N, \& Carmichael L, (2001). Evidence for evoluation of canine parvovirus type 2 in Italy. J Gen Virol. 82, 3021 - 3025.

3. Charmichael LE, (1994). Canine parvovirus type -2.An evolving pathogen of dogs.Ann Vet Med. 135, 459- 464.

4. Decaro N, Martella V, Desario C, Bellacicco AL, Camero M, Manna L, D'Aloja D, Buonavoglia C, (2006). First detection of canine parvovirus type $C$ in pups with haemorragica enteritis in Spain. J Vet Med. 53, 468-472.

5. Decaro N, Desario C, Addie DD, Martella V, Vieira JM, Elia G, Zicola A, Davis C, Thompson G, Thiry E, Truyen U, and Buonavoglia C, (2007). Molecular Epidemiology of Canine Parvovirus, Europe. Emerg Infect Dis. 13, 1222 - 124.

6. Dei Giudici S, Cubeddu T, Giagu A, Sanna G, Rocca S, Oggiano A, (2017). First molecular characterization of canine parvovirus strains in Sardinia, Italy. Arch Virol. 017, 3457-3.
7. Hong C, Decaro N, Desario C, Tanner P, Pardo CM, Sanchez S, Buonavoglia C, Saliki TJ, (2007). Occurrence of canine parvovirus type $2 c$ in the United States. J Vet Diagn Invest. 19, 535-539.

8. Horiuchi M, Goto N, Ishiguro M, Shinagawa J,(1994). Mapping of determinants of the host range fort he canine cells in the genome of the canine parvovirus using canine parvovirus/mink enteritis virus chimeric viruses.J Gen Virol.75, 1319 - 1328.

9. Lin CN, Chien $\mathrm{CH}$, Chio MT, Chueh LL, Hung MY, Hsu HS, (2014). Genetic characterization of type 2 a canine parvovirus from Twaiwan reveals the emergence of an tle324 mutation in VP2. Virol J. 11, 39.

10. Jeoung S, Ahn S, Kim D, (2008). Genetic analysis of VP2 gene canine parvovirus isolates in Korea. J Vet Med Sci. 70, 719 - 722.

11. Ntafis V, Xylouri E, Kalli I, Desario C, Mari V, Decaro N, Buonavoglia C,(2010). Characterization of Canine parvovirus 2 variants circulating in Greece J Vet Diagn Invest. 22, 737-740.

12. Martella V, Decaro N, Elia G, Buonavoglia C, (2005). Surveillance activity for canine parvovirus in Italy. J Vet Med. 52, 312-315.

13. Meers J, Kyaw-Tanner M, Benzink Z, Zwijnenberg R, (2007) Genetic analysis of canine parvovirus from dogs in Australia. Aust Vet J. 85, 392-396.

14. Miranda C, and Thompson G, (2016). Canine parvovirus: the worldwide occurrence of antigenic variants. J Gen Virol, 97, 2043 - 2057.

15. Mittal M, Chakravarti S, Mohapatra KJ, Chug KP, Dubey R, Upmanuyu V, Narwal PS, Kumar A, Churamani CP, Kanwar $\mathrm{SN},(2014)$. Molecular typing of canine parvovirus strains circulating from 2008 to 2012 in an organized kennel in India reveals the possibility of vaccination failure. Infec Genet Evol. 23, 1- 6 .

16. Mukhopadhyay HK, Matta SL, Amsaveni S, Antony PX, Thanislass J, Pillai RM, (2014). Phylogenetic analysis of canine parvovirus partial VP2 gene in India. Virus Genes. 48, 89 - 95.

17. Raj MJ, Mukhopadhyay KH, Thanislass J, Antony XP, Pillai MR, (2010). Isolation, molecular characterization and phylogenetic analysis if canineparvovirus. Infec Genet Evol. 10, 1237 - 1241.

18. Soma T, Taharaguchi S, Ohinata T, Ishii H, Hara M, (2013). Analysis of the VP2 protein gene of canine parvovirus strains from affected dogs in Japan. Res Vet Sci. 94, 368 - 371.

19. Tamura K, Stecher G, Peterson D, Filipski A, and Kumar S, (2013). MEGA6: Molecular Evolutionary Genetics Analysis version 6.0. Mol Biol Evol. 30, 2725 - 2729.

20. Timurkan M, Oguzoglu T, (2015). Molecular characterization of canine parvovirus (CPV) infection in Turkey. Vet Ital. 51, 39 - 44.

21. U. Truyen, (2006). Evolution of canine parvovirus-a need for new vaccines? Vet Microbiol. 117, 9-13

22. Yesilbag K, Y1lmaz Z, Ozkul A, \& Pratelli A, (2007). Aetiological role of viruses in puppies with diarrhoea. Vet Rec. 161, 169 - 170.

23. Y1lmaz Z, Pratelli A, \&Torun S, (2005). Distribution of antigen types of canine parvovirus type 2 in dogs with hemorrhagic enteritis in Turkey. Turk J. Vet Anim Sci. 29, 1073 - 1076.

24. Zhang R, Yang S, Zhang W, Zhang T, Xie Z, Feng H, Wang S, Xia X, (2010). Phylogenetic analysis of the VP2 gene of canine parvoviruses circulating in China.Virus Genes. 40, 397- 402.

25. Zhao Z, Liu H, Ding K, Peng C, Xue Q, Yu Z, Xue Y, (2016). Occurance of canine parvovirus in dogs from Henan province of China. Vet Res. 12, 138 - 145.

26. Zienius D, Lelesius R, Kavaliauskis H, Stankevicius A, Salomskas A, (2016). Pol J Vet Sci. 19, 187-196.

27. Zourkas E, Ward MP, Kelman M, (2015). Canine parvovirus in Australia: A comperative study of reported rural and urban cases. Vet Microbiol. 121, 198 - 203. 